Division of Geological \& Geophysical Surveys

PRELIMINARY INTERPRETIVE REPORT 2007-2

\title{
BROOKIAN SEQUENCE STRATIGRAPHIC CORRELATIONS, UMIAT FIELD TO MILNE POINT FIELD, WEST-CENTRAL NORTH SLOPE, ALASKA
}

\author{
by
}

Paul L. Decker

April 2007

THIS REPORT HAS NOT BEEN REVIEWED FOR TECHNICAL CONTENT (EXCEPT AS NOTED IN TEXT) OR FOR CONFORMITY TO THE EDITORIAL STANDARDS OF DGGS.

\author{
Released by \\ STATE OF ALASKA \\ DEPARTMENT OF NATURAL RESOURCES \\ Division of Geological \& Geophysical Surveys \\ 3354 College Rd. \\ Fairbanks, Alaska 99709-3707
}

$\$ 15.00$ 



\title{
BROOKIAN SEQUENCE STRATIGRAPHIC CORRELATIONS, UMIAT FIELD TO MILNE POINT FIELD, WEST-CENTRAL NORTH SLOPE, ALASKA
}

\author{
by \\ Paul L. Decker \\ Alaska Division of Oil \& Gas
}

\begin{abstract}
Between the Umiat and Milne Point fields in the west-central North Slope, the Brookian sequence consists of at least three fundamental depositional cycles: the Nanushuk-Torok, the Tuluvak-Seabee, and the Prince Creek-Schrader Bluff-Sagavanirktok systems. These three major progradational cycles consist of lithostratigraphically defined, genetically linked formations, and are separated by major, regionally correlatable flooding events that correspond to dramatic rises of relative sea level and substantial shifts of the paleoshoreline. Considerable complexity is recognized within the Maastrichtian-Campanian portions of the Prince Creek and Schrader Bluff formations in the study area by identifying and correlating internal transgressive flooding surfaces and sequence boundaries across widely varying depositional environments in a generally dip-oriented stratigraphic correlation section. This work underscores the necessity of better defining the subsurface expression and significance of the intra-Paleocene contact between the Prince Creek and Sagavanirktok formations, which is considered a probable nonmarine sequence boundary where it has been identified in outcrop.
\end{abstract}

\section{Introduction}

Since the mid-1990s there has been a marked increase in exploration for and production of oil from Brookian sequence reservoirs on the North Slope. Recent industry successes have clarified the significance of previously obscure intervals, and have brought widespread recognition of the important role of stratigraphic traps in Brookian petroleum systems. However, very few recently published sections depict Brookian correlations and sequence stratigraphic relationships in a detailed yet regional manner across the Colville foreland basin. Major revisions to the formal Brookian stratigraphic nomenclature by Mull and others (2003) render previously published correlation figures (e.g., Molenaar and others, 1986, 1987) inconsistent with current usage, further underscoring the need for updated subsurface interpretations.

Compared to formations of the Ellesmerian sequence, which were deposited as widespread, lithologically distinct units on a relatively stable passive margin, specific horizons of the Brookian sequence foreland basin fill can be difficult to identify reliably from well logs in isolated penetrations. Cross section A-A' (sheet 1 of this report) was constructed to illustrate in a semi-regional sense the vertical succession and proximal to distal depositional variations within the Brookian sequence in the northern part of the Colville basin of the west-central North Slope (figs. 1, 2). In particular, it clarifies relationships of several producing or potentially productive Brookian reservoirs to one another and to outcrops of the same formations. The represented section is approximately $127 \mathrm{mi}$ long measured between points of control, uses a mean sea level datum, and is intended for plotting at a vertical scale of 1 in equals $500 \mathrm{ft}$. 


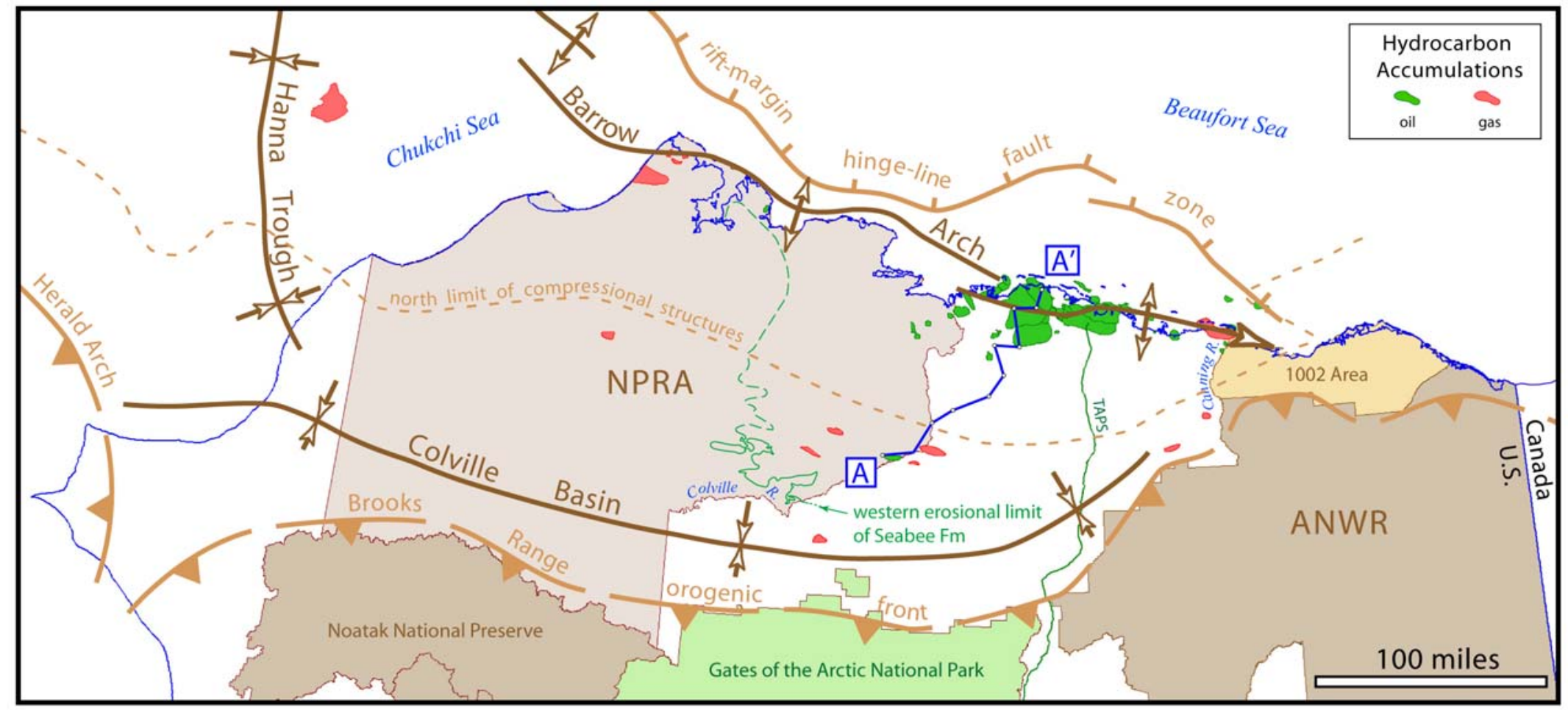

Figure 1. Index map of northern Alaska, showing location of correlation section $A-A^{\prime}$ relative to regional geologic and geographic features discussed in the text, known accumulations of oil and gas, and political boundaries. Major tectonic features are adapted from Grantz and others (1990) and Bird (2001). TAPS = Trans-Alaska Pipeline System. 


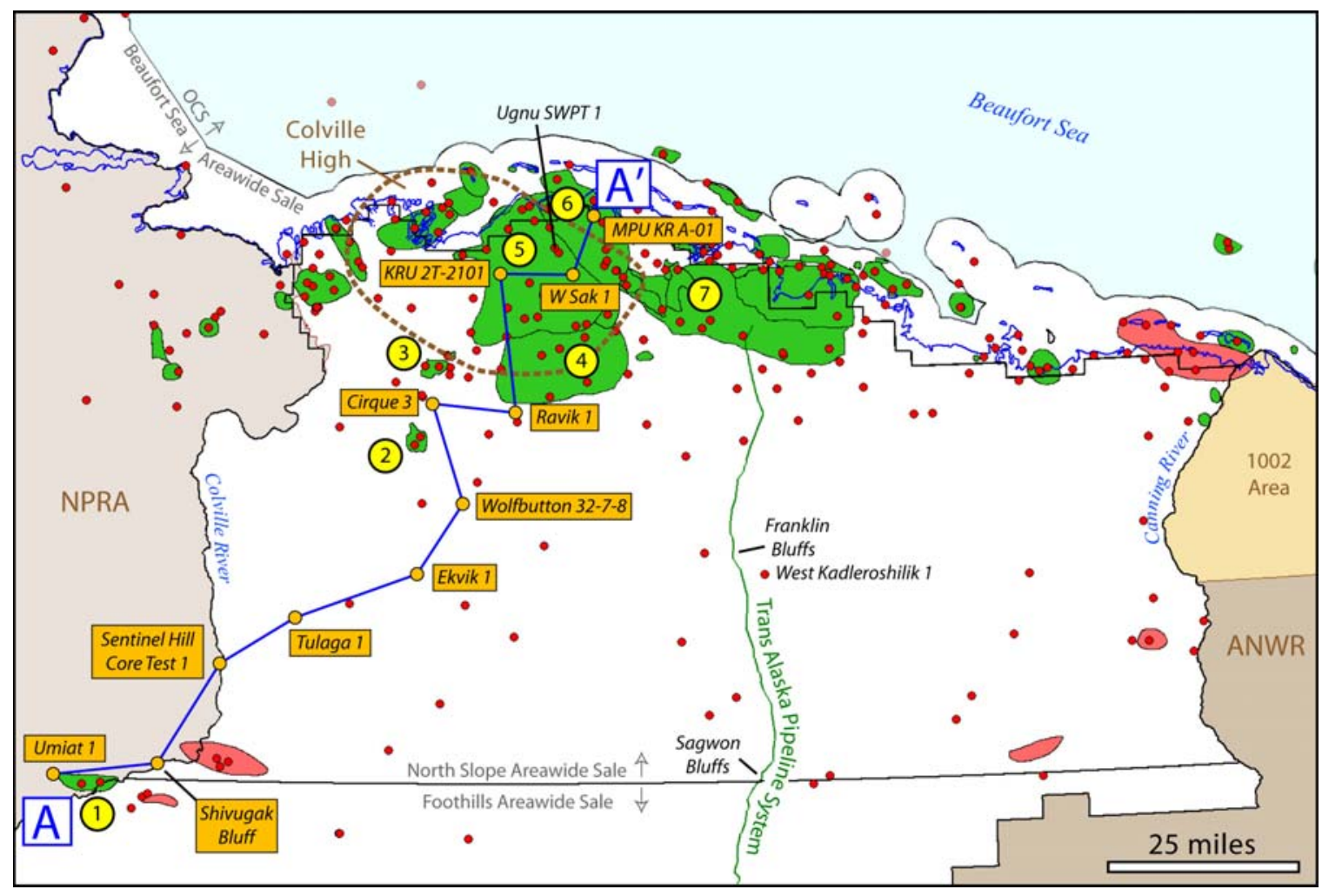

Figure 2. Map of the central North Slope showing wells, outcrop localities, oil and gas accumulations, and other features discussed in the text. Numbered oil and gas accumulations are as follows: (1) Umiat, (2) Meltwater, (3) Tarn, (4) West Sak, (5) Kuparuk River, (6) Milne Point, and (7) Prudhoe Bay. Unlabeled red dots are exploration wells not discussed in the text. Dashed outline of the Colville High is the 2 $\mathrm{km}$ depth contour at the base of the Brookian sequence from Grantz and others (1990).

The correlations shown in sheet 1 are interpretive, based primarily on well log character, lithologic descriptions from mud logs and an outcrop measured section, as well as biostratigraphic control. Stratigraphic names are consistent with the formally revised Brookian sequence nomenclature of Mull and others (2003), but also include informal subsurface names and intervals defined in Alaska Oil and Gas Conservation Commission (AOGCC) Conservation Orders and related public documents. As such, section A-A' is one of the first publicly available products to explore in detail the implications of carrying the newly revised, outcrop-based, lithostratigraphically defined, nomenclature into the subsurface of the major producing areas on the Barrow Arch. The current version of section A-A' reinterprets certain stratigraphic relationships from those depicted in a preliminary version, which was released in 2005 by the Alaska Division of Oil and Gas without accompanying text. 


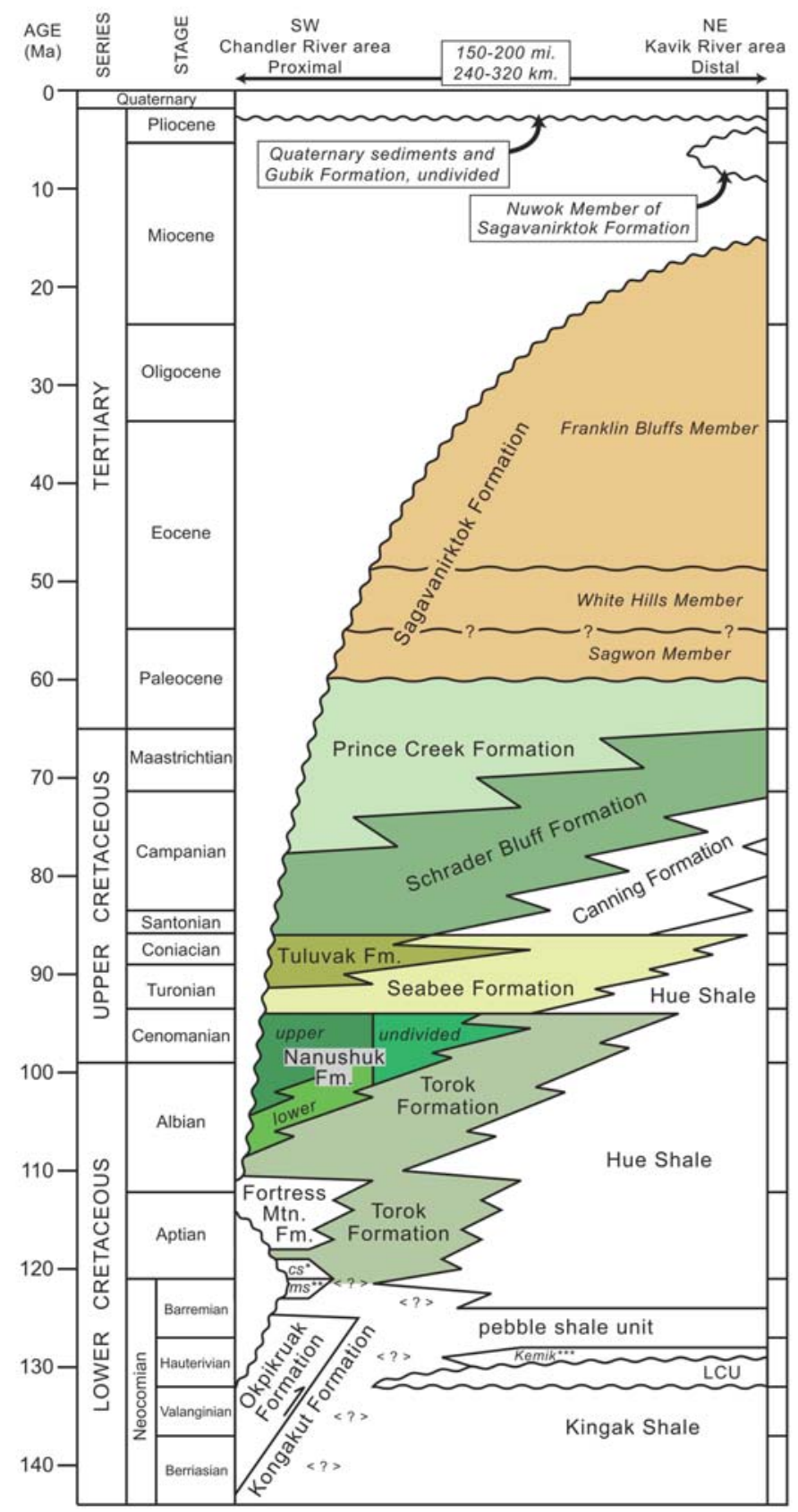

Figure 3. Chronostratigraphic column for the Colville basin, northern Alaska, showing the revised Brookian sequence stratigraphic nomenclature and ages (from Mull and others, 2003). See the original reference for detailed explanation of abbreviations and symbols. 
The following discussion follows the stratigraphic section (fig. 3) from older to younger, and considers time-equivalent, genetically related units together to highlight key observations with a minimum of description. The discussion also includes certain relevant interpretations and observations that are derived from information other than the well data presented here. A brief description of Beaufortian stratigraphy and rift tectonism reflected by the oldest correlated horizons is included to provide pre-Brookian context. The lower Brookian Okpikruak and Fortress Mountain formations, which were deposited closer to the Brooks Range in Early Cretaceous time, are not discussed. Those units are well developed in the southern and western parts of the Colville basin, and are absent from the line of section due to pinchout. Another important Brookian unit, the Upper Cretaceous to Tertiary Canning Formation, is dramatically under-represented in this section. These slope to basin deposits are correlative with the Prince Creek, Schrader Bluff, and Sagavanirktok formations, but are better characterized in outcrop and subsurface studies east and northeast of this section (e.g., Molenaar, 1983; Molenaar and others, 1987).

\section{Lower Cretaceous Unconformity and Upper Kuparuk Formation}

Uplift of the Barrow Arch rift shoulder during Hauterivian time led to widespread subaerial exposure and erosion of lower Neocomian and older strata, creating the Lower Cretaceous Unconformity (LCU; Grantz and May, 1983; Grantz and others, 1988; Bird, 1985, 1992, 2001; Hubbard and others, 1987). The ensuing transgression persisted into Barremian (perhaps locally into Aptian) time. The amount of erosion at LCU varies widely, and is greatest on the crest of the several en-echelon structural culminations that together constitute the regional Barrow Arch. The LCU surface is disconformable in most places, but angular discordance is evident in compressed cross sections and seismic profiles traversing the Barrow Arch (e.g., Cole and others, 1994; Miller and others, 2000). Erosion generally decreases to the south, and the LCU beneath the Colville Basin transitions into a correlative conformity with little or no missing section. The Colville High (Hudson and others, 2006) is a major present-day culmination along the Barrow Arch in the central North Slope (figs. 1, 2; the region of the KRU Tabasco 2T-210 and West Sak River State 1 wells on sheet 1 ), but that area largely coincided with a relatively low-lying trough during Neocomian time. This was a saddle on the rift margin that saw only minor LCU erosion into the underlying regressive deposits of the lower Kuparuk Formation, and provided accommodation for accumulation of transgressive shallow marine sands of the upper Kuparuk Formation (Carman and Hardwick, 1983; Masterson and Paris, 1987). The end of Upper Kuparuk sand deposition occurred as the transgression continued, shutting off subaerial sand sources and replacing formerly sandy environments with lower energy shelfal waters.

\section{Pebble Shale Unit (Kalubik Formation) and Highly Radioactive Zone}

The informally named pebble shale unit and highly radioactive zone (HRZ) reflect the progressive transgressive deepening above LCU that accompanied foundering of the Beaufortian rift shoulder and simultaneous subsidence of the Brookian Colville 
foreland basin. The pebble shale unit (equivalent to the Kalubik Formation proposed by Carman and Hardwick, 1983) is interpreted to represent mostly low energy shelfal or deeper deposits (Blanchard and Tailleur, 1983; Bird and Molenaar, 1987). This unit contains outsized sand, pebbles, and even cobbles and boulders in some locations (Gil Mull, personal communication, 2005), which apparently were delivered as dropstones sourced from the remaining shoaling to subaerially emergent highs on the Barrow Arch. Details of pebble shale lithofacies, stacking patterns, and sequence stratigraphic systems tracts as defined in Canning River outcrops are presented by Macquaker and others (1999).

The HRZ (Carman and Hardwick, 1983) is generally considered synonymous with the gamma ray zone (GRZ; Tailleur and others, 1978) that Molenaar and others (1987) included in the lower part of the Lower to Upper Cretaceous Hue Shale. In the correlations depicted in sheet 1, the HRZ is restricted to the Lower Cretaceous condensed shale that directly overlies the pebble shale unit and is below the downlapping clinoforms of the Torok Formation and younger basin filling units. The characteristic gamma ray log motif of the HRZ is recognizable nearly everywhere across the North Slope, but the condensed section is thickest and most conspicuous to the east and north where influx of silt and coarser grained material from Brookian provenance areas was minimized.

\section{Nanushuk and Torok Formations}

The Nanushuk and Torok formations are thick, genetically coupled Aptian(?)Cenomanian units deposited in topset (nonmarine to shelf) and deepwater (slope to basin) environments, respectively. These formations established a pattern of dominantly westto-east axial fill that continued in the foreland basin throughout Cretaceous and Tertiary time. Together with the partly time-equivalent Fortress Mountain Formation, the Nanushuk and Torok constitute a large volumetric fraction of the Colville foreland basin sedimentary fill; ranging in combined depositional thickness from zero near the middle of section A-A' (sheet 1$)$ to more than 10,000 $\mathrm{m}(\sim 33,000 \mathrm{ft})$ in the far western North Slope (Bird and Andrews, 1979). This enormous sediment influx coincided with major mid-Cretaceous uplift and erosion in the Brooks Range, which has been variously attributed to (1) documented major extensional exhumation in the hinterland (southern flank) of the Jurassic-Neocomian compressional orogen (Miller and Hudson, 1991; Vogl, 2002; Vogl and others, 2002) or (2) a continuation or renewal of Brookian contraction (Oldow and others, 1987; Bird and Molenaar, 1992, Till and Snee, 1995; Cole and others, 1997).

Few details of the internal architecture of these formations are apparent in cross section A-A', which includes only two widely separated Nanushuk Formation penetrations (Umiat 1 and Tulaga 1 on sheet 1), both of which represent only the younger portions of the dominantly eastward-prograding Torok-Nanushuk depositional system. Most of the Torok-Nanushuk succession lies west of cross section A-A' (fig. 1), in NPRA and further west. The topset-clinoform stratal surfaces shown in the Torok Formation on the cross section are schematic depictions of prominent seismic reflectors with up to several thousand feet of depositional relief between the shelf margin and toeof-slope (Houseknecht and Schenk, 2001; 2005). Dozens of mappable horizons within this enormous sedimentary wedge are evident in the regional USGS seismic grid that 
covers NPRA. Careful mapping of these clinoforms and their shelf margins may illuminate details of Torok-Nanushuk depositional history and relative sea level fluctuations, particularly during late Albian-Cenomanian time (Houseknecht and Schenk, 2001). Toe-of-slope sandstones are broadly distributed near the base of the Torok Formation, and are encountered in nearly all well penetrations, but the delivery of sand to submarine fan settings varied over time as a function of higher order sequence cyclicity (McMillen, 1991). Of particular interest to oil and gas exploration are seismic indications of falling stage and lowstand systems tract deposits, in which stratigraphically trapped forced regressive shoreface, shelf-edge delta, and turbidite reservoirs are most likely to occur.

Seven of the twelve wells drilled on the Umiat anticline tested oil from the Nanushuk Formation in penetrations structurally higher than the Umiat 1 well (Collins, 1958; Brosgé and Whittington, 1966; Molenaar, 1982). Nanushuk sandstones in the vicinity include a variety of deltaic, fluvial, and estuarine facies (Huffman, 1985; Huffman and others, 1988; Houseknecht and Schenk, 2005). In the Umiat area, topset strata transition from dominantly progradational marine to nonmarine facies in the lower and middle Nanushuk to dominantly retrogradational paralic facies in the uppermost Nanushuk. Farther east at Tulaga 1, located approximately 15 miles west of the terminal Nanushuk-Torok shelf margin (sheet 1), the topsets lack compelling evidence of nonmarine deposits, although the overall transition from progradational stacking to retrogradational stacking can be inferred from well logs at a true vertical depth of about $5,000 \mathrm{ft}$. The gradual transgressive backstepping during deposition of the uppermost Nanushuk (Cenomanian) was ended by an apparently abrupt, large-scale transgression that drove the shoreline far to the west, at least as far as east-central NPRA. Much more insight into regional variations in the depositional history of the Nanushuk Formation is published elsewhere (e.g., Huffman, 1985; Molenaar, 1988), including new interpretations by LePain and others (in prep).

\section{Tuluvak and Seabee Formations}

The nonmarine to shallow marine conglomerates and sandstones of the Tuluvak Formation and the offshore to deepwater shales and turbidite sandstones that constitute all but the lowermost Seabee Formation form a dominantly progradational Brookian genetic couplet. This progradation was preceded by a major transgression that terminated the Nanushuk-Torok depositional system and deposited the organic-rich, condensed mudstone at the base of the Seabee Formation. This basal condensed mudstone is referred to as the Shale Wall facies by Houseknecht and Schenk (2005, p. 3), who conclude this marine drowning extended as far west as the Chukchi Sea (fig. 1). Certainly, at maximum flood, the shoreline had shifted at least as far west as east-central NPRA, where outcrop and seismic data define the western erosional limit of definite Seabee Formation at the Holocene unconformity surface (fig. 1; Mayfield and others, 1988). It should be clarified that the term "Shale Wall facies" as used by Houseknecht and Schenk (2005) and as adopted in this paper is restricted to the dark gray to black, bentonite- and organic-rich condensed mudstone facies, particularly the basal Seabee transgressive systems tract and maximum flood deposits, and is not synonymous with the former Shale Wall member of the Seabee Formation (as defined by Detterman and others [1963] and abandoned by 
Mull and others [2003]). In the now abandoned definition by Detterman (1963), the Shale Wall member included all of what is now defined as Seabee Formation.

Prograding eastward across the underlying shelf built during Nanushuk-Torok deposition, the accommodation-limited early Tuluvak-Seabee system developed seismically evident clinoforms that range from a few hundred to nearly a thousand feet in height (fig. 3 of Houseknecht and Schenk, 2005); much smaller than the several thousand-foot height of the older Torok clinoforms. These Seabee Formation clinoforms downlap on and merge into the Shale Wall facies of the previous transgressive systems tract. Higher-order depositional sequences within the prograding Seabee Formation are recognized in outcrops along the Colville River at Umiat and farther west (Phillips and others, 1990; Houseknecht and Schenk, 2005), where lowstand, transgressive, and highstand deposits all reflect the shelfal and shallower environments west of the underlying Nanushuk-Torok final shelf margin.

Because early Tuluvak-Seabee progradation took place on top of the broad, low gradient Nanushuk-Torok platform, it is likely that even during lowstand cycles, little sediment would have traveled far beyond the toes of the early Seabee clinoforms. Most deposition occurred inboard (west) of the final Nanushuk shelf margin, leaving the deep basin east of the final Torok clinoform largely deprived of sediment. However, published age constraints from the lower Seabee formation west and east of the final Nanushuk shelf margin are imprecise, and do not preclude the interpretation (Houseknecht and Schenk, 2005) that some of the deepwater sandstones and mudstones of the informally named Bermuda interval to the east may correlate to shallower water lowstand systems tracts in Umiat area outcrops.

The Bermuda interval of the Seabee Formation contains the producing Cenomanian-Turonian turbidite reservoirs of the Tarn and Meltwater oil pools (AOGCC, 1998, 2001). The Bermuda wedge occurs near what is locally the base of the Seabee, lying immediately above condensed shales believed to be the deepwater equivalent of the Shale Wall facies (sensu Houseknecht and Schenk, 2005) that overlies the Nanushuk Formation to the west. These lower Seabee strata onlap the relict Torok slope, and are overlain by younger, high-relief Seabee clinoforms (sheet 1). These spatial relationships indicate that Bermuda turbidite deposition must have begun when the corresponding shoreline (in the Tuluvak facies) was still somewhere west of the final Nanushuk shelf edge, but just how far west is difficult to establish. The difficulty in transporting large volumes of Tuluvak-Seabee lowstand sediments for long distances across the broad, lowgradient Nanushuk-Torok platform argues for the likelihood that most of the Bermuda turbidites may have been derived from Tuluvak-facies topsets and Seabee-facies clinoforms as their toes approached the underlying paleoshelf edge. Bermuda sands are interpreted as slope-apron deposits delivered via headward eroding slope gullies (Morris and others, 2000, 2002; Hastings and others, 2001). It is possible that much of the Bermuda wedge was fed by lowstand erosion into the quasi-stable topsets and clinoforms perched very near the edge of the inherited shelf.

Bermuda sands attain substantially better reservoir quality in the Tarn and Meltwater fields than in the wells correlated on section A-A' (sheet 1). Wolfbutton 32-78 penetrated an equivalent distal facies and Cirque 3 is located between the axes of the main sand feeder systems. In core, the Bermuda reservoir averages 21 percent porosity with 10 md permeability at Tarn (AOGCC, 1998), and 20 percent porosity with 12 md 
permeability at Meltwater (AOGCC, 2001). On well logs, the Bermuda interval is recognized as a relatively sandy package bounded above and below by relatively pure shales. The underlying shale in particular, here considered equivalent to the Shale Wall facies, exhibits a motif of high gamma ray, low sonic velocity, and low bulk density (e.g., Wolfbutton 32-7-8); hallmarks of condensed deepwater facies. Northeast of the Bermuda wedge, this shale appears to merge with the shale that overlies the Bermuda, and the combined shales become even more condensed (thinner). These distal Seabee shales are equivalent to the lowermost part of the Upper Cretaceous Hue Shale, and eventually coalesce with underlying Lower Cretaceous HRZ beyond the limit of the Torok Formation. Subsequent Seabee mudstones are interpreted to downlap on this early Seabee-Hue Shale condensed section.

Seabee Formation stratal geometries and sediment distribution changed dramatically when the downlapping Seabee clinoforms reached the final NanushukTorok shelf margin, and began to fill the much deeper basin to the east. The slope of the prograding Seabee clinoforms abruptly became taller, steeper, and less stable. An array of mostly down-to-the-basin normal faults parallel to the final Nanushuk shelf edge is evident in the Tuluvak topsets in seismic sections (fig. 3 of Houseknecht and Schenk, 2005), presumably driven by compaction of the dramatically thickened Seabee Formation to the east. Depositional growth on these faults may have provided accommodation for anomalously thick, multi-parasequence shoreface systems during the final stages of Tuluvak Formation deposition. Such an interval, which exhibited exceptional reservoir quality, was cored in the Kuparuk Uplands Ekvik 1 well

The Tuluvak-Seabee progradational cycle ended with a major transgressive event that shifted the shoreline westward from the Ekvik 1 area to somewhere in NPRA. The overlying transgressive systems tract consists of highly radioactive, laterally continuous, tuffaceous shales of the lower Schrader Bluff, which were deposited in low-energy shelfal settings (Kuparuk Uplands Ekvik 1 and Wolfbutton 32-7-8) and draped the underlying outer shelf and slope (Cirque 3 and Ravik State 1), and the equivalent highly radioactive, tuffaceous, probably oil-prone, condensed source rock facies of the Hue Shale deposited in the deepwater environment (West Sak River State 1 and Milne Point Unit KR A-01 wells).

\section{Prince Creek and Schrader Bluff Formations}

Together, the genetic couplet of the Prince Creek and Schrader Bluff formations span a considerable period of Late Cretaceous to Paleocene time, and are differentiated on the basis of depositional environment (nonmarine and shallow marine to shelf settings, respectively) more than by geologic age. Until recently, the age of both formations was considered to be limited to the Late Cretaceous (Detterman and others, 1963; Brosgé and Whittington, 1966), but Mull and others (2003) explicitly redefined the contact between the upper Prince Creek and the overlying Sagwon Member of the Sagavanirktok Formation at Sagwon Bluffs (that member's type locality), such that the revised Prince Creek Formation now includes some lower Paleocene strata. This revision, together with Mull and others' (2003) clarified definition of this unit as the shallow marine and shelfal equivalent of the Prince Creek Formation logically implies that the Schrader Bluff also should also locally range up into the Paleocene, where marine facies occur outboard 
(eastward) of the shoreline that fringed the coastal plain deposits of the upper Prince Creek Formation. However, all of the section interpreted as marine Schrader Bluff on section A-A' (sheet 1 ) is probably of Late Cretaceous age.

Under the old definition, the Schrader Bluff Formation was subdivided into three formal members (Gryc, 1951; Whittington, 1956). Recognizing that the members cannot be reliably distinguished lithologically, Mull and others (2003) abandoned the member nomenclature, recommending that the formation be broken into informal lower, middle, and upper parts where appropriate. In section A-A' (sheet 1) two widely correlatable internal surfaces provide a basis for such a three-fold regional subdivision of the Schrader Bluff Formation; a lower sequence boundary and an upper flooding surface/transgressive surface of erosion.. However, because of the highly time-transgressive nature of the Prince Creek and Schrader Bluff contact, the age of the locally-referenced "upper" portion of the Schrader Bluff will vary from place to place. For example, Flores and others (2007a, 2007b) refer to the upper part of the Schrader Bluff Formation in describing the stratigraphy exposed along the Colville River, but in a more regional context, those strata are assigned to the lower Schrader Bluff (sheet 1).

The southwestern-most and oldest Prince Creek and Schrader Bluff horizons shown on the cross section A-A' (sheet 1) are from those Colville River outcrops, approximately $10 \mathrm{mi}$ downstream from Umiat (Flores and others, 2007a, 2007b; Mull and others, 2003). The Shivugak Bluff measured section, simplified from Flores and others (2007a), includes two interpreted sequence boundaries, which are correlated in section A-A' to two sequence Campanian boundaries in the continuously cored Sentinel Hill Core Test 1. In the core, both surfaces constitute an abrupt change from marine Schrader Bluff deposition to nonmarine Prince Creek conditions; the repetition of this change clearly demonstrates the fundamentally intertonguing, time-transgressive nature of the contact between these lithostratigraphically defined formations. At Shivugak Bluff, the upper sequence boundary exhibits pronounced paleotopographic relief and is interpreted as an incised paleovalley (Flores and others, 2007a). Based on palynomorph assemblages in the Sentinel Hill Core Test 1 (irf Group, Inc., 2006; Flores and others, 2007b), this surface is intra- (probably late-) Campanian in age, and is thought to correlate basinward to a widespread horizon that is recognized in seismic data as a conspicuous submarine mass wasting and/or erosion surface (fig. 3 of Houseknecht and Schenk, 2005). Informally referred to here as the mid-Campanian unconformity (MCU), this horizon incised the underlying lower Schrader Bluff, Tuluvak-Seabee, and Hue Shale over a wide range of water depths. The expression of the MCU surface in individual wells is highly variable, but it commonly represents a sharp dislocation of depositional environments, placing relatively proximal lithofacies over more distal units. This important surface is chosen here to separate the lower Schrader Bluff from the middle Schrader Bluff and equivalent slope facies of the lower Canning Formation.

A key observation drawn from section A-A' (sheet 1) is that the intertonguing Schrader Bluff and Prince Creek intervals in the Shivugak Bluff outcrops and Sentinel Hill Core Test 1 are probably entirely older than the main reservoirs in the same formations at the West Sak, Schrader Bluff, Orion, Polaris, and Ugnu oil accumulations further northeast. Publicly available biostratigraphic interpretations are consistent with this relationship; Werner (1987) identified the West Sak sands and the basal part of the overlying Ugnu interval as Maastrichtian in age, and assigned the rest of the Ugnu to the 
Paleocene, whereas at Sentinel Hill Core Test 1, the Schrader Bluff and Prince Creek range from early to late Campanian in age (irf Group, Inc., 2006; Flores and others, 2007b).

The portion of the Prince Creek Formation above the incised upper sequence boundary at Shivugak Bluff (MCU) is regarded here as time-equivalent to the middle part of the Schrader Bluff Formation and equivalent facies of the lower Canning Formation (sheet 1). This interval includes the Tabasco oil reservoir, whose age is reported simply as Campanian (AOGCC, 1998). The Tabasco reservoir comprises two lithofacies: an older, broadly distributed, thin-bedded, upward coarsening, shelf-margin deltaic sandstone facies and a younger, more locally distributed, amalgamated sandstoneconglomerate facies (AOGCC, 1998). Only the amalgamated sandstone-conglomerate facies is present in the KRU Tabasco 2T-210 well on section A-A' (sheet 1). This facies has a sharp-based, generally blocky log motif and is interpreted as an incised valley fill association (ARCO Alaska, Inc., 1998; Konkler and others, 2000),

The erosional sequence boundary at the base of the Tabasco incised valley is documented in 3D seismic data by "sharp truncation of underlying clinoforms" (Konkler and others, 2000). The recognition of clinoforms in this underlying mudstone unit is consistent with the barrel-shaped log motif exhibited in nearby wells (Ravik State 1, West Sak River State 1, and Milne Point Unit KR A-01), and supports the interpretation that this interval represents a proximal tongue of the lower Canning Formation, which thickens substantially and includes younger rocks to the north and east of the line of section. The basal Tabasco sequence boundary has apparently been removed elsewhere on the cross section by the mudstone-draped transgressive surface of erosion that caps the Tabasco interval.

There is little lithologic evidence for marine deposits of the middle and upper Schrader Bluff Formation southwest of the Kuparuk Uplands Ekvik 1 well on section AA'. Strata in the upper 2,000 ft of the Tulaga 1 well are interpreted from mudlogs and wireline logs as dominantly coaly coastal plain deposits (Prince Creek Formation). A thin coal-bearing tongue in the Ekvik 1 well (approximately 2,800 ft TVD; sheet 1) is abruptly overlain by a widely distributed shelfal shale. These beds are interpreted to record a substantial regressive shift of the shoreline followed by transgressive flooding and ravinement. This flooding surface is highly correlatable in the marine facies and is chosen on section A-A' (sheet 1 ) as the boundary between the middle and upper parts of the Schrader Bluff Formation. Apart from this substantial regressive-transgressive episode, the sedimentary record of middle and upper Schrader Bluff and equivalent Prince Creek deposition represents mainly aggradational sedimentation, with a relatively stationary shoreline (which results in a relatively vertical, interfingered formation contact) that separates the Prince Creek facies to the southwest from correlative shallow marine Schrader Bluff facies to the northeast.

The nature of the upper Schrader Bluff-Prince Creek facies boundary/formation contact changed dramatically shortly before the end of Maastrichtian time. Across the northeastern two-thirds of section A-A', nonmarine latest Maastrichtian to Paleocene strata of the Prince Creek Formation (the informally recognized Ugnu sands) prograded rapidly across the previously shallow marine environment of the underlying upper Schrader Bluff Formation (including the informal West Sak sands and equivalents). 
Clearly, the abrupt, widespread shift to nonmarine facies at the formation contact marks a major regressive pulse, probably either a sequence boundary or forced regression.

The Cretaceous-Tertiary ( $\mathrm{K}-\mathrm{T}$ ) boundary is placed within the lower part of the Ugnu sands, rather than at their base (Werner, 1987), an interpretation supported by unpublished log correlations to the nearby Ugnu SWPT-1 well, where Frederiksen and others (1998) defined the boundary through palynological analysis of closely spaced core samples. The K-T boundary has been reported as an unconformity in the Prudhoe Bay area (Wiggins, 1976) and Milne Point Unit (AOGCC, 1990), but it is considered conformable in the Kuparuk area (Werner, 1987), where Frederiksen and others (1998) observed that "little if any of the uppermost Cretaceous section seems to be missing" across the surface.

It is tempting to interpret the widespread regressive facies shift at the base of the Ugnu interval as the sedimentary response to the onset of contractional reactivation throughout the Brooks Range foothills province, which has been dated at $60+/-5$ Ma by fission track cooling ages (O’Sullivan, 1996; Blythe and others, 1996; Moore and others, 2004). However, this would not be entirely consistent with the available control on either the uplift ages or the position of the $\mathrm{K}-\mathrm{T}$ boundary. The position of the major lithostratigraphic contact/sequence boundary one hundred feet or so below the biostratigraphically placed $\sim 65-66 \mathrm{Ma} \mathrm{K}-\mathrm{T}$ boundary dates the contact as slightly older than the documented uplift age range (55-65 Ma). If this depositional shift was tectonically driven, current age constraints would indicate that it occurred very early rather than during peak or post-uplift stages.

Given the lateral variability inherent in terrestrial depositional environments, few firm regional correlations can be made within the dominantly nonmarine Prince CreekSagavanirktok section. The nonmarine correlation horizons drawn in section A-A' appear to represent significant facies shifts, but are not necessarily reliable timelines. The contact between the Prince Creek and Sagavanirktok formations as redefined in outcrop by Mull and others (2003) is defined only in a single area-the vicinity of Sagwon Bluffs along the Sagavanirktok River near the Dalton Highway/Trans-Alaska Pipeline corridor (fig. 2). Coal-bearing nonmarine beds that have been shown to interfinger with marine sandstones of the Schrader Bluff Formation, and that were formerly included in the Sagwon Member of the Sagavanirktok Formation have been reassigned to the Prince Creek Formation. The revised contact separating them from overlying Sagwon Member sandstones and conglomerates is interpreted to be a sequence boundary (Mull and others, 2003). At present, there is no clear regional criterion for placing this contact in the subsurface. In section A-A' (sheet 1) it has been arbitrarily picked at the base of a particularly sand- and gravel-rich package with a thick, blocky log motif that occurs several hundred feet above the informally defined Ugnu interval (Werner, 1987; AOGCC, 1990, 1997, 2003, 2004), at a candidate (albeit cryptic) sequence boundary. Regardless of the contact's precise position, Mull and others' (2003) extension of the range of the Prince Creek into the lower Paleocene provides a firm basis for including the nonmarine Ugnu sands and equivalents in the Prince Creek Formation. 


\section{Sagavanirktok Formation}

As noted above, there may be no well-defined, regionally recognizable subsurface boundary between the Paleocene and younger Sagavanirktok Formation and the Upper Cretaceous to Paleocene Prince Creek Formation. Both are dominantly nonmarine in outcrop, but are known to interfinger with or even include nearshore marine clastic rocks. If there is, in fact, a regional sequence-bounding unconformity at the contact, as postulated by Mull and others (2003), it will probably be difficult to recognize within non-marine sections based on well logs alone. This uncertainty is reflected in the dashed line representing the Sagavanirktok-Prince Creek contact in section A-A' (sheet 1).

Mull and others (2003) recognize and assign revised ages to four members of the Sagavanirktok Formation. From oldest to youngest, these are the Sagwon (late Paleocene), White Hills (late Paleocene? to early Eocene), Franklin Bluffs (early Eocene to Miocene), and Nuwok (Miocene? to Pliocene?) members.

The West Sak River State 1 and Milne Point Unit KR A-01 wells of section A-A' (sheet 1) both penetrate intervals within the Sagavanirktok Formation that have upwardcoarsening log motifs suggestive of progradational shallow marine parasequences. In the Franklin Bluffs area south of Prudhoe Bay, dinoflagellate cysts indicate nearshore marine or estuarine environments in the lower Franklin Bluffs member (Frederiksen and others, 2002), and an upward-coarsening regressive shallow marine log motif is well developed in the upper White Hills member in the West Kadleroshilik 1 well (fig. 2). Based on generalized correlations to wells with age zonations labeled in Molenaar and others (1986), the portion of the Sagavanirktok Formation represented in section A-A' (sheet 1) is probably Paleocene to Eocene in age, roughly corresponding to the Sagwon and White Hills members of Mull and others (2003), and the Staines Tongue of the Sagavanirktok Formation and Mikkelsen Tongue of the Canning Formation of Molenaar and others (1987). Further biostratigraphic information and detailed correlations that tie the wells of section A-A' to well control and outcrop type sections in the Sagavanirktok RiverWhite Hills area may lead to a much better understanding of stratigraphic subdivisions of the Sagavanirktok Formation in the major producing areas of the central North Slope.

\section{Summary}

Three major genetic cycles are recognized in the Brookian sequence in the northern part of the Colville Basin of the west-central North Slope between the Umiat and Milne Point fields: the Nanushuk-Torok, the Tuluvak-Seabee, and the Prince CreekSchrader Bluff-Sagavanirktok systems. Each cycle is dominated internally by regressive stratal geometries that correspond to east- or northeastward progradation during highstand and lowstand conditions. Strata from these three cycles are separated from each other by relatively thin but readily correlatable transgressive to maximum flooding deposits that correspond to major westward shifts of the paleoshoreline. Stratigraphic correlations within each of these fundamental genetic units at the semi-regional scale illustrate the highly time-transgressive nature of the contacts between these lithostratigraphically defined formations, and clarify the stratigraphic relationships between reservoir-prone Brookian intervals. 
In addition to these general conclusions, the correlations of section A-A' (sheet 1) suggest several important observations specific to the stratigraphic architecture of the Prince Creek-Schrader Bluff-Sagavanirktok system.

1. On a regional scale, two key surfaces-a Campanian sequence boundary with substantial paleotopographic and paleobathymetric relief (MCU), and a late Campanian to Maastrichtian flooding surface-divide the dominantly marine Schrader Bluff Formation into lower, middle, and upper portions.

2. The lower part of the Schrader Bluff Formation (early to late Campanian) interfingers with the Prince Creek Formation at Shivugak Bluff and in the Sentinel Hill Core Test 1 well on the Colville River, whereas the middle and upper parts of the Schrader Bluff Formation (late Campanian to late Maastrichtian) interfinger with the Prince Creek Formation in the area between the Tulaga 1 and Kuparuk Uplands Ekvik 1 wells.

3. A pronounced regressive facies shift occurred with the depositional onset of the (informal) Ugnu sands of the Prince Creek Formation during latest Maastrichtian time, possibly linked to early phases of contractional reactivation throughout the Brooks Range foothills.

4. The intra-Paleocene contact between the dominantly terrestrial Prince Creek and Sagavanirktok formations, defined in Sagwon Bluff area outcrops as a candidate sequence boundary (Mull and others, 2003), is difficult to place with confidence in the west-central North Slope subsurface. Future sequence stratigraphic correlations in wells farther east might better define this formation contact and its relationship to named and unnamed tongues recognized in the lower Sagavanirktok and upper Canning formations.

\section{Acknowledgments}

The author is indebted to a large number of colleagues from industry, agencies, and academic institutions for sharing their collective knowledge, ideas, and enthusiasm concerning North Slope stratigraphy and the evolution of the Colville basin. This paper benefited tremendously from constructive reviews by Ken Bird, David Houseknecht, and Marwan Wartes and from editing by Ellen Daley.

\section{References Cited}

Alaska Oil and Gas Conservation Commission, 1990, Conservation Order No. 255 (Schrader Bluff Pool Rules): Anchorage, AK, 6 p.

Alaska Oil and Gas Conservation Commission, 1997, Conservation Order No. 406 (West Sak Pool Rules): Anchorage, AK, 11 p.

Alaska Oil and Gas Conservation Commission, 1998a, Conservation Order No. 435 (Tabasco Pool Rules): Anchorage, AK, 8 p.

Alaska Oil and Gas Conservation Commission, 1998b, Conservation Order No. 430 (Tarn Pool Rules): Anchorage, AK, 7 p.

Alaska Oil and Gas Conservation Commission, 2001, Conservation Order No. 456 (Meltwater Pool Rules): Anchorage, AK, 9 p. 
Alaska Oil and Gas Conservation Commission, 2003, Conservation Order No. 484 (Polaris Pool Rules): Anchorage, AK, 13 p.

Alaska Oil and Gas Conservation Commission, 2004, Conservation Order No. 505 (Orion Pool Rules): Anchorage, AK, 12 p.

ARCO Alaska, Inc., 1998, Exhibit \#3: Stratigraphic cross section A-A', Tabasco pool rules public hearing testimony: Alaska Division of Oil and Gas Public Unit Files.

Bird, K.J., and Andrews, J., 1979, Subsurface study of the Nanushuk Group, North Slope, Alaska, in Ahlbrandt, T.S., ed., Preliminary geologic, petrologic, and paleontologic results of the study of Nanushuk Group rocks, North Slope, Alaska: U.S. Geological Survey Circular 794, p. 32-41.

Bird, K.J., 1985, The framework geology of the North Slope of Alaska as related to oilsource rock correlations, in Magoon, L.B., and Claypool G.E., eds., Alaska North Slope oil/rock correlation study: American Association of Petroleum Geologists Studies in Geology \#20, p. 3-29.

Bird, K.J., 1988, Structure-contour and isopach maps of the National Petroleum Reserve in Alaska, in Gryc, G., ed., Geology and exploration of the National Petroleum Reserve in Alaska, 1974 to 1982: U.S. Geological Survey Professional Paper 1399, p. 355-377.

Bird, K.J., 2001, Alaska: a twenty-first-century petroleum province, in Downey, M.W., Threet, J.C., and Morgan, W.A., eds., Petroleum provinces of the twenty-first century: American Association of Petroleum Geologists Memoir 74, p. 137-165.

Bird, K.J., and Molenaar, C.M., 1987, Stratigraphy, in Bird, K.J., and Magoon, L.B., eds., Petroleum geology of the northern part of the Arctic National Wildlife Refuge, northeastern Alaska: U.S. Geological Survey Bulletin 1778, p. 37-59.

Bird, K.J., and Molenaar, C.M., 1992, The North Slope foreland basin, Alaska, in Leckie, D.A., and Macqueen, R.W., eds., Foreland basins and foldbelts: American Association of Petroleum Geologists Memoir 55, p. 363-393.

Blanchard, D.C., and Tailleur, I.L., 1983, Pebble shale (Early Cretaceous) depositional environments in National Petroleum Reserve in Alaska (NPRA) [abs.]: American Association of Petroleum Geologists Bulletin, v. 67, p. 424-425.

Blythe, A.E., Bird, J.M., and Omar, G., 1996, Deformational history of the central Brooks Range, Alaska; results from fission-track and ${ }^{40} \mathrm{Ar} /{ }^{39} \mathrm{Ar}$ analyses: Tectonics, v. 15, p. 440-455.

Brosgé, W.P., and Whittington, C.L., 1966, Geology of the Umiat-Maybe Creek region, Alaska, with Heavy-mineral studies of the Umiat-Maybe Creek region, by R.H. Morris: U.S. Geological Survey Professional Paper 303-H, p. 501-638.

Carman, G.J., and Hardwick, P., 1983, Geology and regional setting of Kuparuk oil field, Alaska: American Association of Petroleum Geologists Bulletin v. 67, p. 1014-1031.

Cole, F., Bird, K., and Howell, D., 1994, Preliminary results of a tectonic subsidence analysis of the central North Slope, Alaska in Till, A.B., and Moore, T., eds., 
Geologic Studies in Alaska by the U.S. Geological Survey, 1993: U.S. Geological Survey Bulletin 2107, p. 115-132.

Cole, F.E., Bird, K.J., Toro, Jaime, Roure, Francois, O’Sullivan, P.B., Pawlewicz, M.J., and Howell, D.G., 1997, An integrated model for the tectonic development of the frontal Brooks Range and Colville Basin $250 \mathrm{~km}$ west of the Trans-Alaska Crustal Transect: Journal of Geophysical Research, v. 102, p. 20,685-20,708.

Collins, F.R., 1958, Test wells, Umiat area, Alaska: U.S. Geological Survey Professional Paper 305-B, p. 71-206.

Detterman, R.L., Bickel, R.S., and Gryc, George, 1963, Geology of the Chandler River region, Alaska: U.S. Geological Survey Professional Paper 303-E, p. 223-324.

Flores, R.M., Myers, M.D., Houseknecht, D.W., Stricker, G.D., Brizzolara, D., Ryherd, T., and Takahashi, K.I., 2007a, Stratigraphy and facies of Upper Cretaceous Schrader Bluff and Prince Creek Formations in Colville River Bluffs, North Slope, Alaska, in Haeussler, P., and Galloway, J.P., eds., Studies by the U.S. Geological Survey in Alaska, 2006: U.S. Geological Survey Professional Paper (in review), 38 p.

Flores, R.M., Stricker, G.D., Decker, P.L, and Myers, M.D., 2007b, Sentinel Hill Core Test 1: Facies and stratigraphic reinterpretation of the Prince Creek and Schrader Bluff Formations, North Slope, Alaska, in Haeussler, P., and Galloway, J.P., eds., Studies by the U.S. Geological Survey in Alaska, 2006: U.S. Geological Survey Professional Paper (in review), 19 p.

Frederiksen, N.O., Andrle, V.A.S., Sheehan, T.P., Ager, T.A., Collett, T.S., Fouch, T.D., Franczyk, K.J., and Johnsson, M.J., 1998, Palynological dating of Upper Cretaceous to middle Eocene strata in the Sagavanirktok and Canning Formations, North Slope of Alaska: U.S. Geological Survey Open-File Report 98-471, 51 p.

Frederiksen, N.O., Edwards, L.E., Ager, T.A., and Sheehan, T.P., 2002, Palynology of Eocene strata in the Sagavanirktok and Canning Formations on the North Slope of Alaska: Palynology, v. 26, p. 59-93.

Grantz, A., and May, S.D., 1983, Rifting history and structural development of the continental margin north of Alaska, in Watkins, J.S., and Drake, C.L., eds., Studies in continental margin geology: American Association of Petroleum Geologists Memoir 34, p. 77-100.

Grantz, A., May, S.D., and Hart, P.E., 1988, Geology of the Arctic continental margin of Alaska, in Grantz, A., Johnson, L., and Sweeney, J.F., eds., The Geology of North America, v. L, the Arctic Ocean region: Geological Society of America, Boulder, Colorado, p. 257-287.

Gryc, G., Patton, W.W., Jr., and Payne, T.G., 1951, Present Cretaceous stratigraphic nomenclature of northern Alaska: Washington Academy of Sciences Journal, v. 41, p. 159-167.

Hastings, D.S., Morris, W.R., Faust, M.J., and Helmold, K.P., 2001, Reservoir description of the Tarn sand system, North Slope, Alaska, by integration of seismic architecture and turbidite depositional elements [abs.]: American Association of Petroleum Geologists Annual Convention Program, p. A82-A83. 
Houseknecht, D.W., and Schenk, C.J., 2001, Depositional sequences and facies in the Torok Formation, National Petroleum Reserve-Alaska (NPRA), in Houseknecht, D.W., ed., NPRA core workshop: petroleum plays and systems in the National Petroleum Reserve-Alaska: SEPM Core Workshop 21, p. 179-199.

Houseknecht, S.W., and Schenk, C.J., 2005, Sedimentology and sequence stratigraphy of the Cretaceous Nanushuk, Seabee, and Tuluvak Formations exposed on Umiat Mountain, north-central Alaska, in Haeussler, P., and Galloway, J.P., eds., Studies by the U.S. Geological Survey in Alaska, 2004: U.S. Geological Survey Professional Paper 1709B, 18 p., 1 plate.

Hubbard, R.J., Edrich, S.P., and Rattey, R.P., 1987, Geologic evolution and hydrocarbon habitat of the 'Arctic Alaska microplate': Marine and Petroleum Geology v. 4, p. 234.

Hudson, T.L., Nelson, P.H., Bird, K.J., and Huckabay, A., 2006, Exploration history (1964-2000) of the Colville High, North Slope, Alaska: Alaska Division of Geological \& Geophysical Surveys Miscellaneous Publication 136, v. 1.0.2, 32 p.

Huffman, A.C., Jr, ed., 1985, Geology of the Nanushuk Group and related rocks, North Slope, Alaska: U.S. Geological Survey Bulletin 1614, 129 p.

Huffman, A.C., Jr., Ahlbrandt, T.S., and Bartsch-Winkler, S., 1988, Sedimentology of the Nanushuk Group, North Slope, in Gryc, G., ed., Geology and exploration of the National Petroleum Reserve in Alaska, 1974-1982: U.S. Geological Survey Professional Paper 1399, p. 281-298.

irf Group, Inc., 2006, Palynological and micropaleontological evaluation of core samples from the Sentinel Hill Core Test \#1, central North Slope, Alaska (102.6-1,142.5 ft), Alaska Geologic Materials Center Data Report No. 337, 2 p., 1 enclosure.

Konkler, J.L., Hastings, D.S., McGimsey, D.H., Posamentier, H., 2000, Tabasco sands, North Slope, Alaska; An incised valley mapped with 3D seismic data [abs.]: American Association of Petroleum Geologists Bulletin, v. 84, p. 80.

LePain, D.L., McCarthy, P.J., Kirkham, R., in prep., Sedimentology and sequence stratigraphy of the Middle Albian-Cenomanian Nanushuk Formation in outcrop, central North Slope, Alaska: DGGS Report of Investigations.

Masterson, W.D., and Paris, C.E., 1987, Depositional history and reservoir description of the Kuparuk River Formation, North Slope, Alaska, in Tailleur, I., and Weimer, P., eds., Alaskan North Slope Geology, v. 1: Bakersfield, California, Pacific Section, Society of Economic Paleontologists and Mineralogists and Alaska Geological Society, p. 95-107.

Mayfield, C.F., Tailleur, I.L., and Ellersieck, I., 1988, Bedrock geologic map of the National Petroleum Reserve in Alaska, in Gryc, G., ed., Geology and exploration of the National Petroleum Reserve in Alaska, 1974 to 1982: U.S. Geological Survey Professional Paper 1399, p. 187-190. 
McMillen, K.J., 1991, Seismic stratigraphy of Lower Cretaceous foreland basin submarine fans in the North Slope, Alaska, in Weimer, P., and Link, M.H., eds., Seismic facies and sedimentary processes of submarine fans and turbidite systems: New York, Springer-Verlag, p. 289-301.

Miller, E.L., and Hudson, T.L., 1991, Mid-Cretaceous extensional fragmentation of a Jurassic-Early Cretaceous compressional orogen, Alaska: Tectonics, v. 10, p. 781796.

Miller, J.J., Agena, W.F., Lee, M.W., Zihlman, F.N., Grow, J.A., Taylor, D.J., Killgore, M., and Oliver, H.L., 2000, Regional seismic lines reprocessed using post-stack processing techniques: National Petroleum Reserve-Alaska: U.S. Geological Survey Open-file Report 00-286, http://greenwood.cr.usgs.gov/energy/OF00-286/22RLINES.HTM.

Molenaar, C.M., 1982, Umiat field, an oil accumulation in a thrust-faulted anticline, North Slope of Alaska, in Powers, R.B., ed., Geologic studies of the Cordilleran thrust belt: Rocky Mountain Association of Geologists, p. 537-548.

Molenaar, C.M., 1983, Depositional relations of Cretaceous and lower Tertiary rocks, northeastern Alaska: American Association of Petroleum Geologists Bulletin, v. 67, p. 1066-1080.

Molenaar, C.M., 1988, Depositional history and seismic stratigraphy of Lower Cretaceous rocks in the National Petroleum Reserve in Alaska and adjacent areas, in Gryc, G., ed., Geology and exploration of the National Petroleum Reserve in Alaska, 1974-1982: U.S. Geological Survey Professional Paper 1399, p. 593-621.

Molenaar, C.M., Bird, K.J., and Collett, T.S., 1986, Regional correlation sections across the North Slope of Alaska: U.S. Geological Survey Miscellaneous Field Studies MF1907, 1 sheet.

Molenaar, C.M., Bird, K.J., and Kirk, A.R., 1987, Cretaceous and Tertiary stratigraphy of northeastern Alaska, in Tailleur, I., and Weimer, P., eds., Alaskan North Slope Geology, v. 1: Bakersfield, California, Pacific Section, Society of Economic Paleontologists and Mineralogists and Alaska Geological Society, p. 513-528.

Moore, T.E., Potter, C.J., O’Sullivan, P.B., Shelton, K.L., and Underwood, M.B., 2004, Two stages of deformation and fluid migration in the west-central Brooks Range fold and thrust belt, northern Alaska, in Swennen, R., Roure, F., and Granath, J.W., eds., Deformation, fluid flow, and reservoir appraisal in foreland fold and thrust belts: American Association of Petroleum Geologists Hedberg series, no. 1, p. 157-186.

Morris, W.R., Hastings, D.S., Moothart, S.R., Helmold, K.P., and Faust, M.J., 2000, sequence stratigraphic development and depositional framework of deep water slope apron systems, Tarn reservoir, North Slope, Alaska [abs.]: American Association of Petroleum Geologists Annual Convention Program, p. A101. 
Morris, W.R., Hastings, D.S., and Moothart, S.R., 2002, Controls on the distribution of reservoir properties in the Tarn field, North Slope Alaska [abs.]: American Association of Petroleum Geologists, Pacific Section-Society of Petroleum Engineers, Western Region Joint Technical Conference Program and Abstracts, p. 93-94.

Mull, C.G., Houseknecht, D.W., and Bird, K.J., 2003, Revised Cretaceous and Tertiary stratigraphic nomenclature in the Colville Basin, northern Alaska: U.S. Geological Survey Professional Paper 1673, 51 p.

Oldow, J.S., Seidensticker, C.M., Phelps, J.C., Julian, F.E., Gottschalk, R.R., Boler, K.W., Handschy, J.W., and Ave Lallemant, H.G., 1987, Balanced cross sections through the central Brooks Range and North Slope, arctic Alaska: American Association of Petroleum Geologists, 19 p., 8 pl.

O’Sullivan, P.B., 1996, Late Mesozoic and Cenozoic thermo-tectonic evolution of the North Slope foreland basin, Alaska, in Johnson, M.J., and Howell, D.G., eds., Thermal evolution of sedimentary basins in Alaska: U.S. Geological Survey Bulletin 2142, p. 45-79.

Phillips, S., Decker, J., Shane, J.D., Hite, D.M., and Bergman, S.C., 1990, Recognition of depositional sequences in the Upper Cretaceous Seabee Formation, central North Slope, Alaska [abs.]: American Association of Petroleum Geologists Bulletin, v. 74, no. 5 , p. 740.

Tailleur, I.L., Pessel, G.H., and Engwicht, S.E., 1978, Folio, eastern North Slope petroleum province: U.S. Geological Survey Miscellaneous Field Studies Map MF928A (map with tables), 8 p., scale 1:500,000.

Till, A.B., and Snee, L.W., 1995, ${ }^{40} \mathrm{Ar} /{ }^{39} \mathrm{Ar}$ evidence that formation of blueschists in continental crust was synchronous with foreland fold and thrust belt deformation, western Brooks Range, Alaska: Journal of Metamorphic Geology, v. 13, p. 41-60.

Vogl, J.J., 2002, Late-orogenic backfolding and extension in the Brooks Range collisional orogen, northern Alaska: Journal of Structural Geology, v. 24, p. 1,7531,776 .

Vogl, J.J., Calvert, A.T., and Gans, P.B., 2002, Mechanisms and timing of exhumation of collision-related metamorphic rocks, southern Brooks Range, Alaska; Insights from ${ }^{40} \mathrm{Ar} /{ }^{39} \mathrm{Ar}$ thermochronology: Tectonics, v. 21, p. 2-1-2-17.

Werner, M.R., 1987, West Sak and Ugnu sands; Low gravity oil zones of the Kuparuk River area, Alaskan North Slope, in Tailleur, I., and Weimer, P., eds., Alaskan North Slope Geology, v. 1: Bakersfield, California, Pacific Section, Society of Economic Paleontologists and Mineralogists and Alaska Geological Society, p. 109-118.

Whittington, C.L., 1956, Revised stratigraphic nomenclature of Colville Group, in Gryc, G., and others, Mesozoic sequence in Colville River region, northern Alaska: American Association of Petroleum Geologists Bulletin v. 40, p. 244-253.

Wiggins, V.D., 1976, Fossil oculata pollen from Alaska: Geoscience and Man, v. 15, p 51-76. 